\title{
PERFORMANCE OF GROWING PULLETS FED CASSAVA PEEL MEAL DIET SUPPLEMENTED WITH CASHEW NUT REJECT MEAL
}

\author{
RENDIMIENTO DE POLLOS EN CRECIMIENTO ALIMENTADOS CON HARINA DE \\ PELADURAS DE MANDIOCA Y HARINA DE RESIDUOS DE SEMILLA DE ANACARDO
}

\author{
Sogunle,O.M. ${ }^{1 *}$, A.O. Fanimo ${ }^{1}$, S.S. Abiola ${ }^{1}$ and A.M. Bamgbose ${ }^{2}$
}

1Department of Animal Production and Health. University of Agriculture. Abeokuta. Ogun State. Nigeria. ${ }^{2}$ Department of Animal Nutrition. University of Agriculture. Abeokuta. Ogun State. Nigeria.

${ }^{*}$ Corresponding author: jidesogunle@yahoo.com

\section{AdDitiOnAL KEYWORDS}

Growing pullets. Haemoglobin concentration.

\section{SUMMARY}

The performance and blood constituents of growing pullets fed cassava (Manihot esculenta Crantz) peel meal (CPM) diet supplemented with cashew nut (Anacardium occidentale Linn) reject meal (CNM) were studied for 13 weeks using four hundred and thirty-two 9 weeks old Yaafa Brown pullet chicks. The birds were maintained on a grower diet consisting of 3 levels of $\mathrm{CPM}(0,10$ and $20 \%$ ) each supplemented with 4 levels of CNM $(0$, 10,20 and $30 \%$ ) in a $3 \times 4$ factorial experimental layout. The highest weight gain of $7.96 \mathrm{~g} / \mathrm{bird} / \mathrm{day}$ was obtained in diet 3 (0\% CPM and $20 \% \mathrm{CNM}$ ) while the highest feed intake of $107.29 \mathrm{~g} / \mathrm{bird} / \mathrm{day}$ and cost of $1 \mathrm{~kg}$ feed of $\$ 0.31$ were obtained in diet $12(20 \%$ CPM and $30 \%$ CNM). CPM inclusion in the diets significantly $(p<0.05)$ influenced the haemoglobin concentration and the serum total protein. The growing pullets performed poorly with increasing CPM in the diets but had an improved performance, as CNM was included. It was then concluded that the combination of $10 \%$ CPM and $30 \%$ CNM was appropriate for enhanced performance of growing pullets.

\section{RESUMEN}

El rendimiento y contituyentes sanguíneos de pollos en crecimiento alimentados con harina de peladuras de mandioca (Manihot esculenta Crantz) (CPM) suplementados con harina de residuos de semilla de anacardo (Anacardium

Recibido: 16-2-07. Aceptado: 1-10-07.

\section{Palabras clave adicionales}

Pollos en creciomiento. Concentración de hemoglobina.

occidentale Linn) (CNM), fue estudiado durante 13 semanas empleando 432 pollitos Yaafa Brown de nueve semanas. Las aves fueron mantenidas con una dieta de crecimiento consistente en tres niveles de CPM $(0,10$ y $20 \%)$, cada uno de ellos suplementado con cuatro niveles de $\operatorname{CNM}(0,10$, 20 y $30 \%$ ), en un diseño factorial $3 \times 4$. La mayor ganancia de peso fue de 7,96 g/ave/día obtenida con la dieta 3 (0\% CPM y $20 \%$ CNM) mientras que la mayor ingestión de alimento de 107,29 g/ave/día y coste de $1 \mathrm{~kg}$ de alimento de $\$ 0,31$, se registró con la dieta 12 (20\% CPM y $30 \%$ CNM). La inclusión de CPM en las dietas influyó significativamente $(p<0,05)$ sobre la concentración de hemoglobina y proteína sérica total. El rendimiento de los pollos en crecimiento se empobreció al aumentar la proporción de CPM en las dietas, aunque el rendimiento mejoró al incluir CNM. Se concluyó que la combinación de $10 \%$ de CPM y $30 \%$ de CNM, fue apropiada para mejorar el rendimiento de pollos en crecimiento.

\section{INTRODUCTION}

In view of high poultry feed cost resulting from the cost of maize and vegetable protein sources such as soyabean meal, it is almost never profitable to feed protein at a level which will maximize animal performance. Hence, there is a need to find 
an appropriate alternative feed resource which can replace a certain proportion of maize and vegetable protein sources in the diets of growing pullets at a lower cost of production. Many research efforts were invested in the search for alternative energy sources for poultry (Aina, 1990; Eruvbetine et al., 2003). One of such alternatives is cassava. Though it is a staple food for humans, there is increasing interest in its use as a substitute for maize in feeding livestock. The renewed interests in cassava are because of availability throughout the year, efficient production of cheap energy (Hahn and Keyser, 1985), drought tolerance and ability to thrive on marginal soils.

It is noteworthy that the protein content of cassava is of poorer quality (Agunbiade et al., 2001) compared to that of cereal grain. When utilized in replacing cereals in diet for monogastric animals, it becomes imperative to balance for protein deficiencies, which are sometimes expensive. Hence, cashew nut reject meal finds an excellent supplement as both protein and energy source in the diets of poultry (Sogunle et al., 2005). The processing of the raw nut carried out in many of the producing countries revealed that $60-65 \%$ are of commercial value while $35-40 \%$ of the processed nuts are often discarded either as broken or scorched kernels (Fetuga et al., 1974). The discarded nut is said to contain a significant quantity of high protein material, which is particularly useful for feeding monogastric animals. The inclusion of full-fat cashew nut rejects and cassava peel meal in the diets of the growing pullets was studied to determine the effects of the combination on the bird's performance.

\section{MATERIALSAND METHODS}

\section{EXPERIMENTALSITE}

The experiment was carried out in 2006 at the poultry unit (deep litter pen) of the Teaching and Research Farm, University of
Agriculture, Abeokuta, Nigeria $\left(7^{\circ} 15^{\prime} \mathrm{N}, 3^{\circ}\right.$ $\left.25^{\prime} \mathrm{E}\right)$. The period of the experiment was early dry season (i.e. September-November).

\section{EXPERIMENTALBIRDSAND MANAGEMENT}

Four hundred and thirty two (432), 9 weeks-old Yaafa Brown pullet chicks were used for the study that lasted for 13 weeks. The birds were divided into 12 treatment groups with 3 replications of 12 birds each and were managed intensively in a deep litter pen containing wood shavings $(6 \mathrm{~cm}$ deep) as litter material. The diets consisted of three levels $(0,10$ and $20 \%)$ of cassava peel meal with each level supplemented with four levels $(0,10,20$ and $30 \%)$ of cashew nut reject meal (table I).

\section{Chemical ANALYSis}

The proximate compositions of the test ingredients and diets were determined by the method of AOAC (1995). The moisture content was determined by oven- drying the diets and faeces to constant weight at $65^{\circ} \mathrm{C}$ for 26 hours.

\section{BIOCHEMICAL AND HAEMATOLOGICAL ANA- LYSES}

At the $13^{\text {th }}$ week blood samples $(2 \mathrm{ml}$ each) were collected via the wing veins of 3 birds per replicate group into ethylene diamine tetra acetate (EDTA) bottles for serum biochemical analysis (total protein, albumin, globulin, uric acid, creatinine, and glucose) and haematological (packed cell volume, haemoglobin, red blood cell, white blood cell and platelet) analyses. Packed cell volume (PCV), haemoglobin concentration $(\mathrm{Hb})$ and red blood cell (RBC) were determined using Wintrobes microhaematocrit, colorimetry cyanomethaemoglobin method, and improved Neubauer haemocytometer, respectively (Jain, 1986). Serum total protein, albumin and globulin were analyzed colorimetrically using diagnostic reagent kit (Reanal Diagnosztikai Reagents, Keszlet, Hungary) (Varley et al., 1980). 


\section{FEEDING PULLETS WITH CASSAVA PEEL AND CASHEW NUT REJECT MEALS}

\section{Data Collection}

Data were collected daily on the birds' body temperature $\left({ }^{\circ} \mathrm{C}\right)$ which was measured via the wing web using a digital clinical thermometer. The prevailing market prices (\$) of the ingredients at the time of the study were used to calculate the cost of $1 \mathrm{~kg}$ feed consumed and the cost of $1 \mathrm{~kg}$ feed consumed/weight gain (Naira 127.00 $=\$ 1.00$ ).

\section{EXPERIMENTAL DESIGN AND STATISTICAL ANALYSIS}

The experimental layout was a $3 \times 4$ factorial arrangement. The data obtained were subjected to analysis of variance using SAS
(1999). Significant means among variables were separated using Duncan Multiple Range Test (Duncan, 1955) at 5\% level of significance.

\section{RESULTSANDDISCUSSION}

Table II showed that cassava peel meal (\% air-dry basis) contained: 80.95 , dry matter; 5.50, crude protein; 21.36 , crude fibre; 0.67 , ether extract; 66.49, nitrogen-free extract; 21.95 , hydrocyanic acid content $(\mathrm{mg} / \mathrm{kg})$; while, cashew nut reject meal contained: 95.40, dry matter; 21.20 , crude protein; 2.15 , crude fibre; 46.21, ether extract; 3.68 , ash;

Table I. Composition of growers' mash. (Composición del pienso de crecimiento).

\begin{tabular}{|c|c|c|c|c|c|c|c|c|c|c|c|c|}
\hline Diets & 1 & 2 & 3 & 4 & 5 & 6 & 7 & 8 & 9 & 10 & 11 & 12 \\
\hline \multicolumn{13}{|l|}{ Ingredients (\%) } \\
\hline Cassava peel mea & al 0 & 0 & 0 & 0 & 10 & 10 & 10 & 10 & 20 & 20 & 20 & 20 \\
\hline Cashew nut meal & 0 & 10 & 20 & 30 & 0 & 10 & 20 & 30 & 0 & 10 & 20 & 30 \\
\hline Maize & 35.0 & 35.0 & 35.0 & 35.0 & 35.0 & 35.0 & 35.0 & 35.0 & 35.0 & 35.0 & 35.0 & 35.0 \\
\hline Soyabean meal & 10.5 & 8.5 & 6.5 & 4.5 & 12.5 & 10.5 & 8.5 & 6.5 & 15.5 & 13.5 & 11.5 & 8.5 \\
\hline Wheat offal & 48.0 & 40.0 & 32.0 & 24.0 & 36.0 & 28.0 & 20.0 & 12.0 & 23.0 & 15.0 & 7.0 & 0.0 \\
\hline Fish meal & 2.0 & 2.0 & 2.0 & 2.0 & 2.0 & 2.0 & 2.0 & 2.0 & 2.0 & 2.0 & 2.0 & 2.0 \\
\hline Bone meal & 2.0 & 2.0 & 2.0 & 2.0 & 2.0 & 2.0 & 2.0 & 2.0 & 2.0 & 2.0 & 2.0 & 2.0 \\
\hline Oyster shell & 2.0 & 2.0 & 2.0 & 2.0 & 2.0 & 2.0 & 2.0 & 2.0 & 2.0 & 2.0 & 2.0 & 2.0 \\
\hline${ }^{*}$ Vit./Min. premix & 0.25 & 0.25 & 0.25 & 0.25 & 0.25 & 0.25 & 0.25 & 0.25 & 0.25 & 0.25 & 0.25 & 0.25 \\
\hline Salt & 0.25 & 0.25 & 0.25 & 0.25 & 0.25 & 0.25 & 0.25 & 0.25 & 0.25 & 0.25 & 0.25 & 0.25 \\
\hline Total & 100.0 & 100.0 & 100.0 & 100.0 & 100.0 & 100.0 & 100.0 & 100.0 & 100.0 & 100.0 & 100.0 & 100.0 \\
\hline \multicolumn{13}{|c|}{ Determined analysis (\%) } \\
\hline Dry matter & 88.00 & 85.00 & 87.00 & 85.00 & 87.00 & 87.00 & 87.50 & 84.00 & 88.50 & 83.50 & 83.00 & 85.00 \\
\hline Crude protein & 15.01 & 15.24 & 15.68 & 15.76 & 15.37 & 15.55 & 15.40 & 15.39 & 15.45 & 15.53 & 15.61 & 15.22 \\
\hline Crude fibre & 3.17 & 3.19 & 2.91 & 2.86 & 4.01 & 3.91 & 3.65 & 3.42 & 4.21 & 4.07 & 4.18 & 4.23 \\
\hline Ether extract & 4.50 & 3.50 & 4.00 & 5.00 & 4.50 & 3.00 & 5.00 & 4.50 & 5.00 & 3.00 & 4.00 & 3.00 \\
\hline Ash & 23.77 & 23.12 & 23.32 & 23.71 & 23.94 & 22.79 & 23.29 & 23.90 & 23.86 & 23.98 & 23.45 & 23.33 \\
\hline NFE & 53.55 & 54.95 & 54.09 & 52.67 & 52.18 & 54.75 & 52.66 & 52.79 & 50.98 & 53.42 & 52.76 & 54.22 \\
\hline${ }^{* *}$ Calcium & 1.36 & 1.36 & 1.36 & 1.36 & 1.36 & 1.36 & 1.36 & 1.36 & 1.36 & 1.36 & 1.36 & 1.36 \\
\hline${ }^{* *}$ Phosphorus & 0.68 & 0.68 & 0.68 & 0.68 & 0.68 & 0.68 & 0.68 & 0.68 & 0.68 & 0.68 & 0.68 & 0.68 \\
\hline ME(MJ/kg) & 12.60 & 12.61 & 12.62 & 12.63 & 12.10 & 12.11 & 12.13 & 12.14 & 11.58 & 11.59 & 11.60 & 11.64 \\
\hline
\end{tabular}

*Vit./Min. Premix contained: Premix (Embavit No 90) contained Vit. A, 10000000 iu; D, 2000000 iu; E, $12500 \mathrm{iu} ; \mathrm{K}, 1.30 \mathrm{~g} ; \mathrm{B}_{1}, 1.30$; $\mathrm{B}_{2}, 4.00 \mathrm{~g}$; D Calcium-Pantothenate, $1.30 \mathrm{~g} ; \mathrm{B}_{6}, 1.30 \mathrm{~g} ; \mathrm{B}_{12}, 0.01 \mathrm{~g}$; nicotinic acid, $15.00 \mathrm{~g}$; folic acid, $0.05 \mathrm{~g}$; biotin, $0.02 \mathrm{~g}$; Co, $0.20 \mathrm{~g}$; Cu, $5.00 \mathrm{~g}$; Fe, $25.00 \mathrm{~g}$; I, $0.06 \mathrm{~g}$; Mn, 48.00 g; Se, $0.10 \mathrm{~g} ; \mathrm{Zn}, 45.00 \mathrm{~g}$; choline chloride, $200.00 \mathrm{~g}$; BHT, $50.00 \mathrm{~g} .{ }^{* *}$ Calculated.

NFE: Nitrogen-free extract. 
Table II. Proximate composition (\%) of CPM and CNM (air-dry basis). (Composición nutritiva de CPM y CNM, \% sobre material seco al aire).

\begin{tabular}{lcc}
\hline & CPM & CNM \\
\hline Dry matter & 80.95 & 95.40 \\
Crude protein & 5.50 & 21.20 \\
Crude fibre & 21.36 & 2.15 \\
Ether extract & 0.67 & 46.21 \\
Ash & 5.98 & 3.68 \\
Nitrogen-free extract & 66.49 & 26.76 \\
Hydrocyanic acid $(\mathrm{mg} / \mathrm{kg})$ & 21.95 & ND
\end{tabular}

$\mathrm{CPM}=$ Cassava peel meal; $\mathrm{CNM}=$ Cashew nut reject meal; $\mathrm{ND}=$ Not determined.

and $26.76 \%$ nitrogen-free extract. The CPM cyanide content $(21.95 \mathrm{mg} / \mathrm{kg})$ was lower than the optimum tolerable level of $100 \mathrm{mg} /$ $\mathrm{kg}$ reported by Tewe $(1975 ; 1983)$. Hence, the variety used in the study was a low cyanide variety (IITA, 1994). In addition the proximate composition of CNM agreed with the values reported by Sogunle et al. (2005).

The single effect of CPM inclusion levels on the performance of growing pullets shown in table III revealed significant $(p<0.05)$ differences in all the parameters considered except in the mortality and the cost of $1 \mathrm{~kg}$ feed. The average body temperature of the birds was highest $\left(41.5^{\circ} \mathrm{C}\right)$ in $10 \% \mathrm{CPM}$ inclusion comparable to the values obtained at $0 \% \mathrm{CNM}$ inclusion. The values, though increased with increasing CPM in the diets were within the reported values of $41-42^{\circ} \mathrm{C}$ recorded for birds (Marsden and Morris, 1987). The final weight (g/bird) and the weight gain (g/bird/day), feed efficiency and protein efficiency ratio decreased with increasing CPM inclusion in the diets. However, the cost of feed consumed per weight gain and the mortality increased with increasing CPM inclusion in the diets.

Moreover, the single effect of CNM on performance showed depressed significance $(p>0.05)$ in all the parameters considered except in the cost of feed consumed and the cost of feed consumed per weight gain. The average body temperature of the birds $\left({ }^{\circ} \mathrm{C}\right)$ decreased with increasing CNM inclusion in the diets. The cost of $1 \mathrm{~kg}$ feed, cost of feed consumed $(\$)$ and the cost of feed consumed per weight gain $(\$ / \mathrm{g})$ increased with increasing CNM inclusion levels. The highest values of $\$ 0.03$ and $\$ 0.01 / \mathrm{g}$ were obtained in the cost of feed consumed and the cost of feed consumed per weight gain, respectively, at the $30 \% \mathrm{CNM}$ inclusion levels. Mortality decreased with increasing CNM inclusion in the diets thereby confirming the reports of Onifade et al. (1999) that CNM is an excellent feed resource.

CPM inclusion in the diets significantly $(p<0.05)$ influenced the haemoglobin concentration $(\mathrm{g} / \mathrm{dl})$ and the serum total protein $(\mathrm{g} / \mathrm{dl})$. The highest value of 11.55 $\mathrm{g} / \mathrm{dl}$ was obtained at the $10 \%$ CPM inclusion level for haemoglobin while $51.87 \mathrm{~g} / \mathrm{dl}$ was obtained at 20\% CPM inclusion level comparable only to $51.63 \mathrm{~g} / \mathrm{dl}$ at $10 \% \mathrm{CPM}$ inclusion level were obtained for the serum total protein. The red blood cell (RBC) and serum albumin increased with increasing CPM inclusion levels in the diets, but the white blood cell (WBC) decreased with increasing CPM inclusion levels in the diets. On the other hand, increase in CNM inclusion levels significantly $(p<0.05)$ reduced the packed cell volume whereas it showed varying effects on the serum glucose, though, the highest value of $68.21 \mathrm{~g} / \mathrm{dl}$ was obtained at 30\% CNM inclusion.

The interactive effect of CPM and CNM inclusion in the diets on the performance characteristics and cost benefits of growing pullets (table IV) showed no significant $(p>0.05)$ differences in all the parameters across treatments. The average body temperature $\left({ }^{\circ} \mathrm{C}\right)$ of the birds ranged from 41.1 in diets 1 ( $0 \%$ CPM and $0 \%$ CNM) and $11(20 \% \mathrm{CPM}$ and $20 \% \mathrm{CNM})$ to 41.7 in diet 5 (10\% CPM and $0 \% \mathrm{CNM})$. Hence, the highest body temperature was obtained in 


\section{FEEDING PULLETS WITH CASSAVA PEEL AND CASHEW NUT REJECT MEALS}

$\operatorname{diet} 5(10 \% \mathrm{CPM}$ and $0 \% \mathrm{CNM})$. The highest weight gain of $7.96 \mathrm{~g} / \mathrm{bird} /$ day was obtained in diet $3(0 \% \mathrm{CPM}$ and $20 \% \mathrm{CNM})$ while the highest feed intake of $107.29 \mathrm{~g} / \mathrm{bird} /$ day and cost of $1 \mathrm{~kg}$ feed of $\$ 0.31$ were obtained in diet $12(20 \%$ CPM and 30\% CNM). The nature of the feed could probably confer some astringency on them and thereby reduce their palatability and consumption. This could result to a reduced availability of nutrients for growth purposes, hence, the relatively reduced performance of the growing pullets (Ologhobo and Balogun, 1987).

The results of the interactive effects of CPM and CNM diets on the haematological parameters, nitrogen utilization and nutrient digestibility of growing pullets (table V) revealed statistical similarities $(p>0.05)$ in all the parameters considered on hematology across treatments. However, the range of values obtained was within normal

Table III. Single effect of CPM and CNM diets on the performance, cost benefits and haematological parameters (9 birds/treatment) of growing pullets. (Efecto aislado de las dietas con CPM y CNM sobre el rendimiento, coste-beneficio y parámetros hematológicos ( 9 aves por tratamiento) de pollos en crecimiento).

\begin{tabular}{|c|c|c|c|c|c|c|c|c|c|}
\hline & \multicolumn{4}{|c|}{ CPM inclusion levels } & \multicolumn{5}{|c|}{ CNM inclusion levels } \\
\hline & $0 \%$ & $10 \%$ & $20 \%$ & SEM & $0 \%$ & $10 \%$ & $20 \%$ & $30 \%$ & SEM \\
\hline \multicolumn{10}{|l|}{ Performance } \\
\hline Ave. bird body temp. ${ }^{\circ} \mathrm{C}$ & $41.4^{\mathrm{b}}$ & $41.5^{\mathrm{a}}$ & $41.4^{\mathrm{a}}$ & 0.18 & 41.5 & 41.4 & 41.4 & 41.4 & 0.18 \\
\hline Initial wt. (g/bird) & $671.69^{a}$ & $606.60^{\mathrm{b}}$ & $608.55^{b}$ & 20.49 & 632.15 & 636.57 & 624.54 & 622.52 & 17.75 \\
\hline Final wt. (g/bird) & $1364.65^{a}$ & $248.11^{b}$ & $1228.99^{b}$ & 44.98 & 1276.21 & 1292.91 & 1281.16 & 1272.05 & 38.96 \\
\hline Wt. gain (g/bird/day) & $7.59^{\mathrm{a}}$ & $7.05^{\mathrm{b}}$ & $6.82^{\mathrm{b}}$ & 0.33 & 7.08 & 7.18 & 7.21 & 7.14 & 0.29 \\
\hline Feed intake (g/bird/day) & $99.97^{\mathrm{b}}$ & $98.31^{\mathrm{b}}$ & $103.58^{a}$ & 2.17 & 101.86 & 100.51 & 99.17 & 100.95 & 1.88 \\
\hline Feed efficiency & $0.08^{b}$ & $0.07^{a}$ & $0.07^{a}$ & 0.004 & 0.07 & 0.07 & 0.07 & 0.07 & 0.003 \\
\hline Protein intake (g/bird) & $15.41^{\mathrm{b}}$ & $15.17^{b}$ & $16.00^{\mathrm{a}}$ & 0.33 & 15.56 & 15.52 & 15.45 & 15.59 & 0.29 \\
\hline Mortality (\%) & 2.08 & 2.78 & 5.56 & 3.11 & 5.55 & 2.78 & 2.78 & 2.78 & 2.69 \\
\hline \multicolumn{10}{|l|}{ Cost of feed $(\$)$} \\
\hline 1 kg (\$) & 0.27 & 0.28 & 0.29 & 0.002 & 0.25 & 0.27 & 0.29 & 0.31 & 0.20 \\
\hline consumed (\$) & 0.03 & 0.03 & 0.03 & 0.00 & 0.03 & 0.03 & 0.03 & 0.03 & 0.00 \\
\hline consumed/wt.gain $(\$ / g$ & g) 0.004 & 0.004 & 0.004 & 0.00 & 0.003 & 0.004 & 0.004 & 0.004 & 0.00 \\
\hline \multicolumn{10}{|l|}{ Haematology } \\
\hline Packed cell volume (\%) & 32.65 & 34.33 & 34.11 & 2.45 & $35.35^{\mathrm{a}}$ & $34.27^{\mathrm{b}}$ & $33.33^{b}$ & $33.21^{b}$ & 1.01 \\
\hline Haemoglobin (g/dl) & $10.02^{c}$ & $11.55^{\mathrm{a}}$ & $11.33^{b}$ & 0.15 & 11.34 & 11.23 & 11.40 & 11.27 & 0.26 \\
\hline Red blood cell (g/dl) & 4.25 & 4.36 & 4.40 & 0.17 & 3.92 & 3.97 & 3.85 & 3.70 & 0.17 \\
\hline White blood cell $\left(\times 10^{3} / l\right)$ & 5.95 & 5.76 & 5.45 & 0.23 & 5.72 & 5.62 & 5.39 & 5.48 & 1.11 \\
\hline Platelet (g/dl) & 152.30 & 158.00 & 154.33 & 13.11 & 152.13 & 155.38 & 158.66 & 153.32 & 5.13 \\
\hline Serum total protein $(\mathrm{g} / \mathrm{dl})$ & $50.38^{b}$ & $51.63^{\mathrm{a}}$ & $51.87^{\mathrm{a}}$ & 0.84 & 52.65 & 51.53 & 52.65 & 51.91 & 1.33 \\
\hline Serum albumin (g/dl) & 29.10 & 29.45 & 29.52 & 0.48 & 30.10 & 29.70 & 30.36 & 30.00 & 0.68 \\
\hline Serum globulin (g/dl) & 21.28 & 22.18 & 22.35 & 1.32 & 22.55 & 21.83 & 22.29 & 21.91 & 1.12 \\
\hline Serum uric acid (mg/dl) & 3.40 & 3.39 & 3.42 & 0.04 & 3.51 & 3.58 & 3.57 & 3.50 & 1.02 \\
\hline Serum creatinine (mg/dl) & 1.54 & 1.55 & 1.52 & 0.03 & 1.40 & 1.37 & 1.35 & 1.34 & 0.08 \\
\hline Serum glucose $(\mathrm{g} / \mathrm{dl})$ & 61.23 & 61.41 & 61.37 & 1.31 & $65.30^{b}$ & $63.00^{c}$ & $63.00^{c}$ & $68.21^{\mathrm{a}}$ & 1.27 \\
\hline
\end{tabular}

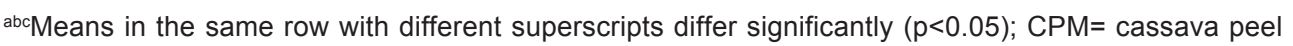
meal; $\mathrm{SEM}=$ standard error of mean; $\mathrm{CNM}=$ cashewnut reject meal: Naira 127.00 $=\$ 1.00$. 
SOGUNLE, FANIMO, ABIOLAAND BAMGBOSE

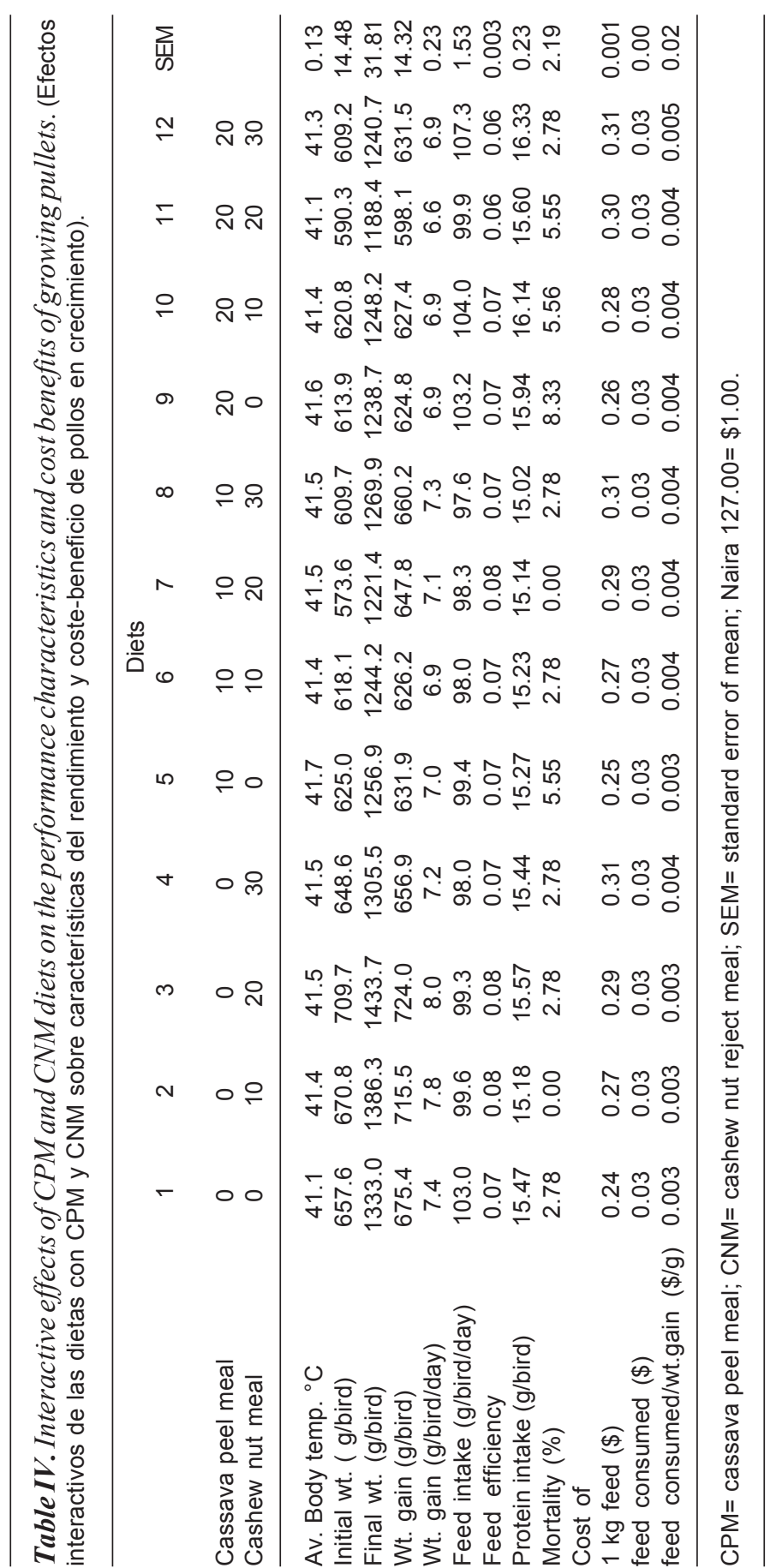

Archivos de zootecnia vol. 58, núm. 221, p. 28. 


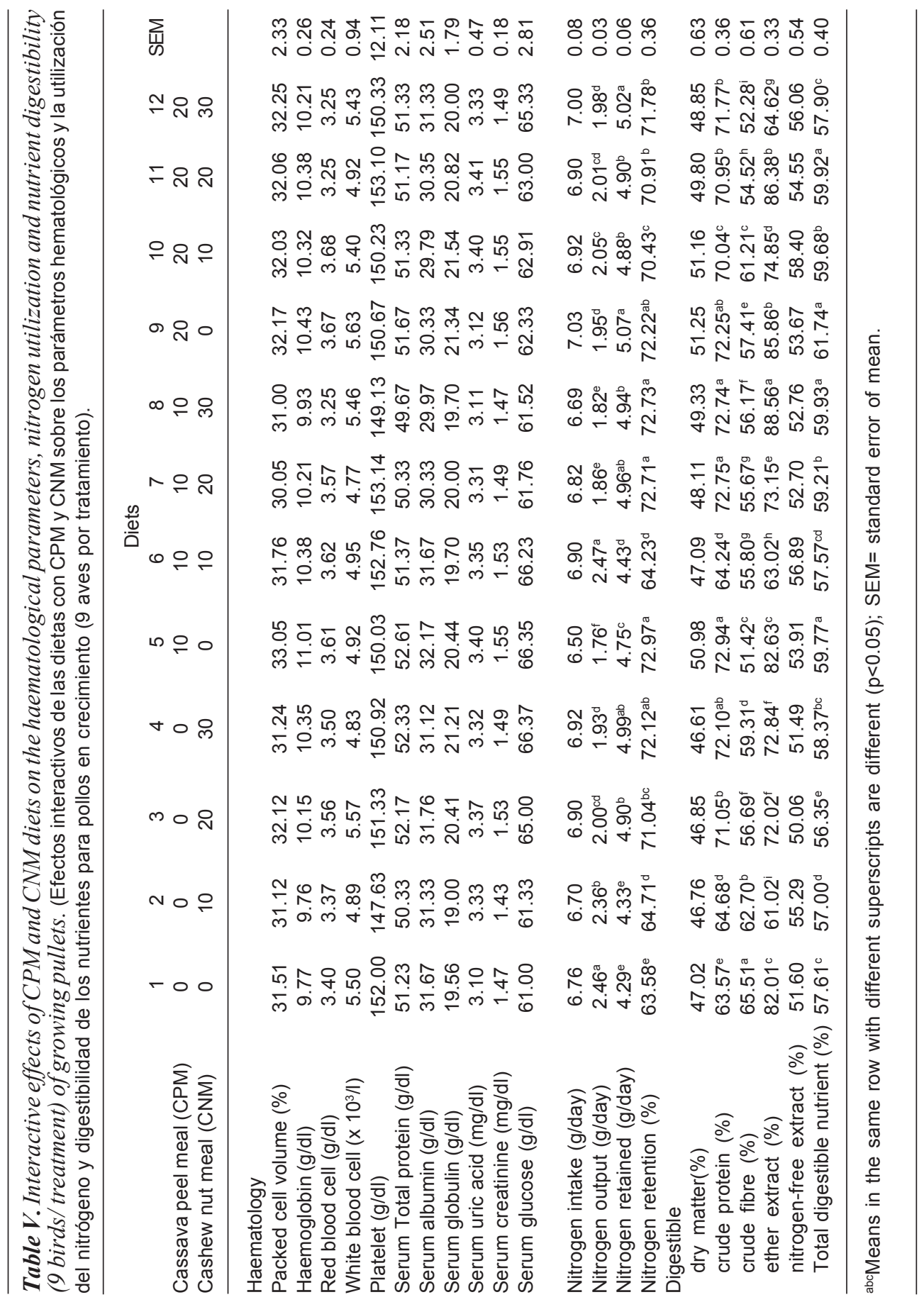




\section{SOGUNLE, FANIMO, ABIOLAAND BAMGBOSE}

limits for avian species (Fraser and Mays, 1986). In addition, the results showed significant $(\mathrm{p}<0.05)$ increase in the nitrogen retention values with increasing inclusion of CPM and CNM in the diets.

From the performance of the growing pullets, it could be adduced that the proportion of dietary energy obtained from fats versus carbohydrates exerted an effect on appetite through a physiological appetite control center responsible to the blood levels of certain nutrients such as glucose and amino acids as reported by Mcleod (1982). Jensen et al. (1970) corroborated these findings that such an effect might involve an increased ability of the chicks to convert dietary energy from fat into stored energy, thereby ensuring a greater increase

\section{REFERENCES}

Agunbiade, J.A., O.A. Adeyemi, O.E. Fasina and S.A. Bagbe. 2001. Fortification of cassava peel meal in balanced diets for rabbits. Nig. J. Anim. Prod., 28: 167-173.

Aina, A.B.J. 1990. Replacing maize with cassava peels in finisher rations for cockerels: The effects on cut-up pieces of eviscerated carcass. Nig. J. Anim. Prod., 17: 17-22.

A.O.A.C. 1995 . Official methods of analysis. $16^{\text {th }}$ edition, Washington, D.C.

Duncan, D.B. 1955. Multiple range and F tests. Biometrics, 11: 1-42.

Eruvbetine, D., I.D. Tajudeen, A.T. Adeosun and A.A. Oloyede. 2003. Cassava (Manihot esculenta) leaf and tuber concentrate in diets for broiler chickens. Bioresource Tech., 86: 277-281.

Fetuga, B.L., G.M. Babatunde and V.A. Oyenuga. 1974. Composition and nutritive value of cashew nut to rats. J. Agric. Fd. Chem., 22: 678-682.

Fraser, C.M. and A. Mays. 1986. The Merck veterinary manual: A handbook of diagnosis. Therapy and disease prevention and control for the veterinarian. $6^{\text {th }}$ edition. Merck and Co., Inc. Rahway, New Jersey, U.S.A. p. 1613-1614

Hahn, S.K. and J. Keyser. 1985. Cassava as a basic food of Africa. Outlook on Agriculture, 4: 95-100.

Homer, A. and J. Schiable. 1980. Poultry feeds and in dietary intake. Whitehead and Fisher (1975) observed that dietary fat improved efficiency of feed utilization of poultry diets and the improvement was attributed to the high energy concentration of fats, while Homer and Schiable (1980) attributed it to both increased density and improved palatability. The latter observation was evident from the use of CNM as a dietary fat supplement in the present study which resulted from a higher energy density of the CNM supplemented diets. Thereby, it confirmed the suggestions of Stockstad et al. (1983) that fats might also increase energy utilization of other dietary constituents. It was then concluded that the combination of $10 \% \mathrm{CPM}$ and $30 \% \mathrm{CNM}$ was appropriate for enhanced performance of growing pullets.

nutrition. $2^{\text {nd }}$ Edition, Avi Pub Company. New York. p. 73.

IITA. 1994. International Workshop on Cassava Safety. Acta Horticulture, ISHC. No 373. 1-4 March. IITA. Ibadan. Nigeria.

Jain, N.C. 1986. Schalm's veterinary haematology. $4^{\text {th }}$ Edition. Lea and Febiger. Philadelphia.

Jensen, L.S., G.W. Shumair and J.D. Latshaw. 1970. "Extra caloric" effect of dietary fat for developing turkeys as influenced by calorie to protein ratio. Poult. Sci., 49: 1697-1704.

Marsden, A. and T.R. Morris. 1987. Quantitative review of the effects of environmental temperatures on food intake, egg output and energy balance in laying pullets. Br. Poult. Sci., 28: 693-704.

Mcleod, J.A. 1982. Nutritional factors influencing carcass fat in broilers -A review. World's Poult. Sci. J., 38: 194-200.

Ologhobo, A.D. and A.M. Balogun. 1987. The value of dried fish silage for pullets and the layer hen. Nig. J. Anim. Prod., 14: 67-76.

Onifade, A.A., O.O. Tewe, O. Okunola and A.O. Fanimo. 1999. Performance of laying pullets fed on cereal free dietary based on maize offal, cassava peels and reject cashewnut meal. Brit. Poult. Sci., 40: 84-87.

SAS Institute. 1999. SAS User's Guide: Statistics.

Archivos de zootecnia vol. 58, núm. 221, p. 30. 


\section{FEEDING PULLETS WITH CASSAVA PEEL AND CASHEW NUT REJECT MEALS}

Inc. Cary, N.C. p. 923.

Sogunle, O.M., A.O. Fanimo, W.O. Biobaku and A.M. Bamgbose. 2005. The feeding value of fullfat cashew nut (Anacardium occidentale Linn) rejects and low cereal diets for broiler chickens. Nig. J. Anim. Prod., 32: 46-53.

Stockstad, E.L.R., T.M. Jukes and W.L. Williams. 1983. Growth promoting effects of aureomycin on various types of diets. Poult. Sci., 32: 10541058.

Tewe, O.O. 1983. Thyroid cassava toxicity in animals. In: Cassava toxicity and thyroid: Research and public health issues ( $F$. Delange and R. Ahluwalia, eds.). Proc. of International
Workshop on Cassava Toxicity. Ottawa, Canada. IDRC-207e. Ottawa. p. 114-118.

Tewe, O.O. 1975. Implications of cyanogenic glucoside of cassava in the growth and reproductive performance of rats and pigs. $\mathrm{PhD}$ thesis, University of Ibadan, Nigeria. $517 \mathrm{p}$.

Varley, H., A.H. Gowelock and M. Bell. 1980. Determination of serum urea using the acetyl monoxide method. Practical biochemistry. $5^{\text {th }}$ Edition. William Heinemann Medical Books Ltd. London.

Whitehead, C.C. and C. Fisher. 1975. The utilization of various fats by turkeys of different ages. $\mathrm{Br}$. Poult. Sci., 16: 481-485.

Archivos de zootecnia vol. 58, núm. 221, p. 31. 